Discursive Space

\title{
Putting Words in Their Mouths: Russian Byliny as Discursive Space
}

\author{
Kate Christine Moore Koppy \\ Marymount University and the University of the District of \\ Columbia Community College \\ Arlington, Virginia, United States of America
}

Abstract

This article follows the Melnitsa Animation Studio into the imagined medieval space of their bogatyr films. With particular focus on Melnitsa's use of the Il'ia Muromets corpus in Илья Муромеи и Соловей Разбойник [Il'ia and the Robber], we consider the complex set of conflicts among characters and ideas that reflect concepts of identity and social issues in contemporary Russia.

In moments of cultural unrest, adaptations of canonical stories serve as a discursive space for the community to redefine itself. In the nineteenth, twentieth, and twenty-first centuries, the byliny [western Slavic heroic epics] have functioned as tools of cultural cohesion at critical moments of national self-redefinition. Most recently, the Студия анимационного кино Мельница_[Melnitsa Animation Studio] (1) has adapted the byliny into animated films for children, in which stories of medieval princes, heroes, and villains become a discursive space for the exploration of social issues in the post-Soviet Russian Federation. Melnitsa's 2007 film Il'ia and the Robber is the most recent example in a steady stream of adaptation and retelling of byliny from the time they were first printed to the present. Along that timeline, there are three moments in which adaptations flourish, and each of these coincides with a crucial moment of redefinition of Russian culture. The nineteenth century recording of these heroic epics, which adapts them from dynamic oral epics to written texts (2), was part of the wave of romantic nationalism that drove scholars across Europe to gather folkloric material as the feudal city-states of the medieval period coalesced into more stable nations. The mid-twentieth century brought another 
surge of adaptation and reproduction as the Soviet government used these heroes to depict good citizenship.

The twenty-first century has been another time of redefinition for the Russian nation as those born since the revolution learn what it means to be not-Soviet and those born since perestroika grapple with what it means to be Russian. This current grappling is evident in the social unrest that we see on the news: demonstrations about women's rights, the crackdown on LGBTQ rights, and uneasiness over Putin's expansion of presidential powers and national borders. As David Gillespie notes, "the literary heritage remains one of the few bastions of certainty and national identity amid chaos and disruption" [Gillespie 1999: 116]. In this environment of restless redefinition, the Melnitsa Animation Studio's adaptations of old stories have been successful at the box office, as television broadcasts, and in merchandising. This article puts particular focus on the changes Melnitsa makes in their adaptation of the Il'ia Muromets (3) corpus to find that Il'ia and the Robber is a complex narrative featuring multi-layered conflicts among the characters.

A significant part of the power of Melnitsa's corpus of films as a discursive space within twenty-first century Russian culture is the status of the films as adaptations of bylina texts whose characters and basic plot are familiar to the audience. Simply being adapted from another text means that the new text has depth provided by the audience's prior knowledge, which may be activated by the title of the adaptation, the names of the characters, or visual symbols associated with the source. In Homo Narrans: The Poetics and Anthropology of Oral Literature, John Niles observes that a community's stories transmit current knowledge, celebrate core values, and create a ludic discursive space [Niles 1999: 2-4]. These stories also reinforce communal bonds because they are shared by all members of the group. In $A$ Theory of Adaptation, Linda Hutcheon argues that adaptation thus enriches the audience's experience of a text by creating "dialogue with the past, for that is what adaptation means for audiences, creates the doubled pleasure of the palimpsest: more than one text is experienced and knowingly so" [Hutcheon 2011: 116]. Audience members who are aware of a text's status as an adaptation engage in an act of collusion with the 


\section{Putting Words in Their Mouths: Russian Byliny as Discursive Space}

text's creator and with one another, and awareness of this collusion forms a community among them. These shared stories, however, do not remain static. Hutcheon describes the way that shared stories become the building material for new narratives, which allude to, draw from, or rework the material presented by the core group, whether satirically or reverently [Hutcheon 2011: 116]. In Adaptation and Appropriation, Julie Sanders further points out that "adaptations can also be oppositional, even subversive" [Sanders 2006: 9]. Sometimes, acts of subversion may be unconscious on the part of the author, and "frequently adaptations and appropriations are impacted upon by movements in, and reading produced by, the theoretical and intellectual arena as much as by their so-called sources" [Sanders 2006: 13]. Viewing Il'ia and the Robber and Melnitsa's other films with a scholarly consciousness of the dynamics of adaptation reveals their complexity.

The bylina is the Slavic world's heroic epic in verse, and the earliest extant written copies of byliny date to the 19th century, when folklorists began collecting them at the margins of the Russian empire--in the north and in the Ural Mountains where they were still being sung in the oral tradition. (4) Like the world's other heroic epics (La Chanson de Roland, Beowulf, The Iliad), byliny contribute to a sense of national identity by reporting the adventures of national heroes grounded in a geographical and historical reality. The content of the two major cycles of byliny places their origins in the cities of Novgorod (5) and Kiev, each of which was a nexus of geopolitical power in the Kievan Rus' period, (roughly the late ninth to the early thirteenth century). During this time, Kiev dominated the trade routes between the Baltic in the north and Byzantium in the south and between Western Europe and the East, and the city of Kiev and its Grand Prince occupied the central position in a constellation of city-states ruled by princes from the same ruling family. (6)

An analogy is often made between the period of the Kievan Rus' and the Western European middle ages, because of their approximate coincidence and also because of the feudal-like distribution of power within Rus' court society. (7) However, for the Slavs this period does not stand between a dark ages and a renaissance as with Western Europe. Rather, it is held up as a sort 
of golden age before the advent of the Mongol yoke in the thirteenth century, a time when Mother Rus' was both powerful and prosperous. The twenty-first century East Slavic cultures of the Russian Federation, the Republic of Belarus, and Ukraine each trace their heritage to this golden age.

Although, the byliny of the Kievan cycle are firmly anchored in the Rus' period by their geographical setting and their social structures, they also transcend this time and place. For most of its history, the Grand Principality of Kiev battled local tribes more than eastern invaders, [Bailey and Ivanova 1998: 26] and the Kievan Повесть Временных Лет [Primary Chronicle] [Likhachev, et. al. 2012] spends pages enumerating the neighboring tribes and the borders of their land, while offering relatively little comment on the more distant Mongols. Often, however, the villains whom the bogatyri [Slavic epic heroes] battle in the byliny represent stereotypes of Mongol adversaries, who conquered the Rus' in the 1230's and held sway over them until Moscow gained independence under Ivan III, Grand Prince of All Rus', in 1480. (8) The byliny set in golden-age Kiev but featuring the Mongol adversaries of a later historical period are the tale singers doing what, today, might be called medievalism. They placed the adversaries of a later day into the discursive space of an imagined medieval past in which the epic heroes could defeat them.

The Kievan cycle bogatyri, Il'ia Muromets, Alësha Popovich, and Dobrynia Nikitich are long-standing icons of Russian popular culture. Each bogatyr has more than one bylina to his name, and these episodic poems circulate independently rather than being knit together into a composite story like the story of Odysseus in Homeric epic. Among these heroes, Il'ia Muromets has been particularly popular for Russian audiences. In their comprehensive Anthology of Russian Folk Epics, Bailey and Ivanova report that the adventure Илья Муромеи и Соловей Разбойник [Ilia and Nightingale the Robber] appears in 132 versions recorded from oral tellers. They further note that "Il'ia Muromets is the subject of more songs and has a more complete epic biography than any other bogatyr" [Bailey and Ivanova 1998: 25]. More recent adaptations condense the many episodic stories of the oral tradition into coherent 


\section{Putting Words in Their Mouths: Russian Byliny as Discursive Space}

films, each of which makes use of plot sequences from multiple adventures.

In addition to drawing on the bylina tradition, Melnitsa's project builds on the strong history of cinematic arts in the Soviet Union to participate in the international cinema industry of the twenty-first century. In his preface to Russia on Reels: The Russian Idea in Post-Soviet Cinema, Richard Taylor notes that the predominance of cinema as a major twentieth century art form was:

Nowhere $[\ldots]$ more apparent than in the former Soviet Union, where Lenin's remark that 'of all the arts for us cinema is the most important' became a cliché....In the age of mass politics Soviet cinema developed from a fragile but effective tool to gain support among the overwhelmingly illiterate peasant masses in the civil war that followed the October 1917 Revolution, through a welter of experimentation, into a mass weapon of propaganda through entertainment that shaped the public image of the Soviet Union. [Taylor 1999: vii]

This public image was also a domestic image, which function as in Niles's model to cohere a group identity, a communication within the social group that defined the new nation through a new corpus of cinematic stories. (9) Where Taylor's model emphasizes a monolithic cinema culture, David MacFaden examines a network of interconnected interests that influenced Soviet publishing, including cinema: ideology enforced by censorship, the need for efficient use of limited resources, commitment to apolitical professionalism, and the concerns and interests of the public audience [MacFaden 2005: xiii-xiv]. (10) In other words, the state-sponsored mass weapon of propaganda described by Taylor also becomes a discursive space for creative pursuits within the constraints set out by censors. Creators and consumers alike were able to communicate complex messages of support and subversion within these state-sanctioned texts.

In the declining Soviet Union of the 1980s, David Gillespie notes "under the new freedoms of glasnost', directors were able to be bolder and show a gift for innovation in their films" [Gillespie 
1999: 118]. One form this expression of innovation took was the chernukha [Slavic film noir] genre. The films of this genre use stark representations of bleak reality to issue powerful calls to social discourse. (11) At the same time, some sectors of the Russian audience rejected the chernukha, "films which offer no positive outlook or spiritual guidance amid the chaos, and [turned] instead to Latin American soap operas screened daily on Russian television" [Beumers 1999: 1]. (12) Although these soap operas were lighter and more hopeful than chernukhi, they were decidedly foreign, with unfamiliar settings and often poor audio dubbing. With the 2004 release of Алеша Поповичь и Тугарин Змей [Alësha Popovich and Tugarin Snake, or Alosha], the creative team at the Melnitsa Animation Studio reached into the familiar plots and characters of the Russian literary canon to create lighthearted and hopeful films with familiar settings. Their adaptations of Russian heroic epics and fairy tales feature well-known characters working through contemporary problems in the safe space of the imagined medieval.

Each of the films in Melnitsa's filmography adapts the corpus of heroic epics to explore social and political issues facing the Russian Federation today-the power of money to corrupt, intergenerational interaction, definition of self with regard to the other(s), issues of gender, the power of the church, and the relationship between citizen and state. Each of these ideas can be seen in all of the movies, but each film foregrounds a subset for closer exploration. Alosha uses Alësha's status as the son of a priest as well as visual imagery of religious artifacts and acts of piety to connect the Orthodox faith to a sense of the Rus' ethnos. An intergenerational group accompanies Alësha on his quest to regain the city of Rostov's treasure from the Tugars, a non-Orthodox Asiatic tribe that had stolen it. Although the society depicted in this film privileges youth, the impetuous young hero and his bride are repeatedly saved by the wisdom of a scrawny old man and a woman bowed with age. Meanwhile, Dobrinya and the Dragon focuses on the way money complicates the power dynamics related to gender and ethnicity within a complex network of obligations among the Grand Prince, his niece, a non-Orthodox tribe, a merchant, and a boiarin [boyar]. (13) The four films which feature the three heroes 


\section{Putting Words in Their Mouths: Russian Byliny as Discursive Space}

together emphasize the heroes' effort toward equality among themselves. In Три Богатыря и Шамаханская Принцесса [How Not to Rescue a Princess] the grand prince has left one of the boiare [boyars] in charge in his absence, and told him to work "с первым богатырем на Руси" [with the first of the Rus' heroes]. Initially, the three heroes argue, “Кто первый? Я!” [Who is first? Me!]. Then they each look sheepish, and the narrator says, "Нет первого среди pавных." [There is not a first among equals.] [Glezin 2010: 15:3516:48].

Although Melnitsa's films may be marketed for children who can certainly enjoy them at the surface level of a good story with engaging visuals, they also exist at a more complex level, which can be appreciated by those members of the audience who have previous experience with the bylina stories. (14) For the knowing audience, the pleasure of the palimpsest is augmented by the reassuring comfort of the familiar. In twenty-first century Russia, for example, Gillespie notes that:

In a time of rapid change and the destruction of old values, the classical literary tradition offers almost ready-made screenplays and familiar material. Furthermore, the literary heritage remains one of the few bastions of certainty and national identity amid chaos and disruption. Both writers and film-makers look into their own culture and history for absolutes in a destabilized world. Reinterpretations of literature, especially in the modern Russian context, also make a statement about contemporary mores or the sociopolitical environment. [Gillespie 1999: 116]

Gillespie's evaluation of the mining of the literary tradition in contemporary Russian cinema and literature exemplifies Hutcheon's general paradigm of adaptation. Even, however, when adaptation is driven by the sort of nostalgic impulses Gillespie describes, it modifies the source text to its own ends. When the adaptation somehow violates the audience's expectations, by contradicting the source text or by moving the characters or plot in a different direction, the mismatch between expectation and 
experience engages the audience as they evaluate and criticize the changes. In the hands of talented artists, the adaptation has great power for social commentary in the space between expectation and adaptation.

To create the 2007 Il'ia and the Robber, Melnitsa adapts the bylina narratives of Илья Муромец и Соловей Разбойник [Il'ia and Nightingale the Robber] and Ссора Ильи Муромща с князем Владимиром [The Quarrel of Il'ia Muromets with Prince Vladimir]. In the byliny, Il'ia Muromets captures Соловей [Solovei] and is rewarded by Великий князь Владимир [Grand Prince Vladimir] with commendations. Much of the plot of this story is retained in the film: Il'ia and Solovei battle one another using strength and cunning, and Il'ia emerges victorious. This conflict begins with Solovei and a band of thugs attacking a village. Il'ia Muromets rides to the rescue, and is able to resist the extraordinary wind created by Solovei's super-power whistle to capture him and turn him over to the authorities in Kiev. Ostensibly, Solovei occupies the villain space of the narrative in that he breaks the law; preys on the innocent villagers, the grand prince, and the hero; and is vanquished at the end. This black-and-white conflict of the hero and villain story arc is the conflict in the surface level story where young or unsophisticated audiences appreciate the film for entertainment. These events, however, also serve to create discursive space within which the more nuanced conflict between takes place.

Underneath the hero-villain story arc, Melnitsa weaves in the bylina story of Il'ia's quarrel with the Grand Prince, which undergoes greater changes from its sources. In the film, the despotic Grand Prince Vladimir releases Solovei, which becomes a point of contention between hero and prince. Solovei is the enemy of both Il'ia Muromets and Grand Prince Vladimir, and these two men chase the villain all the way to Byzantium, but rather than uniting against this common enemy, the hero and the grand prince continue to argue with one another the whole way. Once the action moves out of Kiev, the social structures that constrained the hero and the grand prince disappear, and their interpersonal conflict becomes the main conflict of the narrative. The conflict between epic hero and grand prince is present in nearly every scene in the film, and this adaptation of the 


\section{Putting Words in Their Mouths: Russian Byliny as Discursive Space}

Il'ia Muromets corpus becomes an almost allegorical exploration of the relationship between citizen and state.

Social conflict and arguments between hero and prince are not themselves new; however, the circumstances in Melnitsa's Il'ia and the Robber are a change from earlier iterations of the tradition. In the twenty-seven versions of the bylina The Quarrel of Il'ia Muromets with Prince Vladimir, cataloged by Bailey and Ivanova, the arguments relate to honor and face. Il'ia leaves the court because Vladimir does "not seat the hero in an honored place at a feast" or gives him lesser gifts than those he gives to the boyars [Bailey and Ivanova 1998: 70]. In the 1956 Soviet film The Sword and the Dragon,(15) the argument between prince and hero is orchestrated by the boyars who dislike Il'ia for his peasant origins [21:50, 41:00, 44:00]. The tension present in each version contributes strongly to the overall tenor of the narrative, and the differences among them reflect the changes in the social contexts for which they were created. Melnitsa's 2007 adaptation implicates Grand Prince Vladimir's capricious despotism in the recurring tension between him and Il'ia Muromets. In contrast, the nineteenth-century version presents a stable hierarchy of bogatyr in service to the court of the grand prince, and the 1956 Soviet film creates tension between hero and prince by adding several meddling boyars, members of a noble class out for their own advantage rather than working in service to leader and nation as the peasant (proletarian) Il'ia does. Thus, the cause of the conflict between grand prince and hero is a highly adaptable moment, which can be made to reflect the concerns of the storytellers and audience.

In Melnitsa's adaptations of the Kievan bylina cycle, Grand Prince Vladimir is motivated by money and the power it brings to him. He is imperious and despotic; he issues orders rather than makes requests and responds angrily when his authority is challenged. Two early scenes in Il'ia and the Robber work together to establish the relationship of the grand prince to his people in terms of money and of power. The first is a conversation with an unnamed scribe who suggests that there would be more money in the prince's treasury for social welfare if there were less money for personal expenses.

FOLKLORICA 2016, Vol. XX 
Великий Князь (ВК): Так...Это на социальные нужды....Это-на вооружение.... А вот это- на прочие расходы. [Grand Prince (GP): So....This is for social welfare....This is for the military....And this is for sundry expenses.]

Писарь (П): На прочие много идет... [Scribe (S): That's a lot for sundry expenses...]

ВК: Это да... Это верно... А что, ежели налоги повысит? Скажем, пущай не десятину, a, этак, четвертину платят! Что...что думаешь? [GP: Well yes, that's true...But what if we raise the taxes? Let's say, they'll pay not a tenth, but a quarter! What... What do you think?]

П: А, может, прочее сократить? [S: But, maybe, the sundry expenses could be reduced?]

BК: Но - но! А ты, часом, не демократ?! [GP: What? You are not, perchance, a democrat?]

П: Чур меня! Господь с тобою, князь! [04:30-05:15] [S: Keep away from me! God be with you, prince!] (translation mine)

This scene presents the exploitative relationship Grand Prince Vladimir has with his people, and the visual ratio here is helpful: 


\section{Putting Words in Their Mouths: Russian Byliny as Discursive Space}

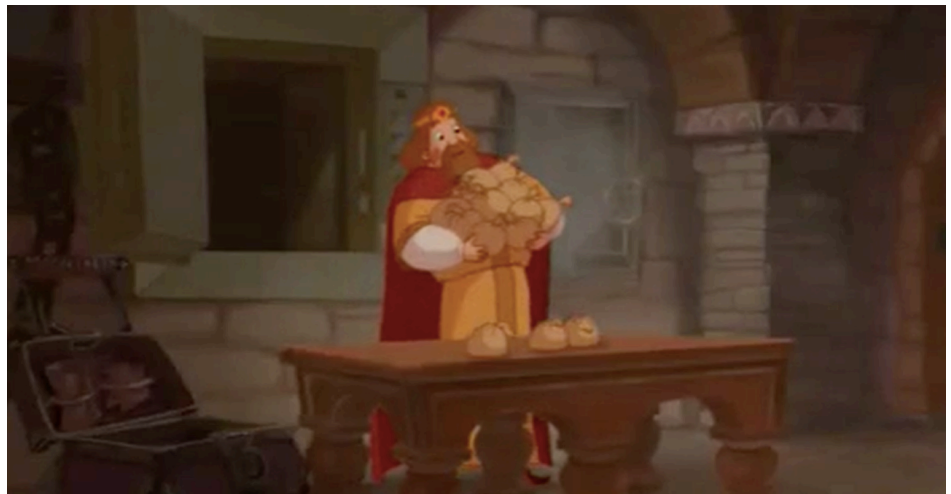

Image 1. The Grand Prince's Treasury. [05:15, Toropchin 2007]

On the table, to the grand prince's right is one bag of money for соииальныле нужды [social welfare], slightly to his left are two bags for вооружение [military], and in his arms an uncountable number for прочие pacxodbl [sundry expenses]. Because Grand Prince Vladimir views the people as a source of revenue, he ponders raising the taxes from a tenth to a quarter in order to better supply funds for social welfare. Although the prince asks what the scribe thinks, he is appalled at the scribe's suggestion to reduce the sundry expenses, and accuses him of being a democrat. The scribe, realizing that he has overstepped his role, reacts with horror at the label, offering protective blessings to ward off the danger of the idea of democracy. Here the word-democrat-as-insult is wielded in response to a challenge to the prince's authority to allocate revenue.

In the second scene that presents the relationship of Grand Prince Vladimir to his people, the hero Il'ia challenges the grand prince's decision to release Solovei whom Il'ia had captured. First the grand prince tells Il'ia that Solovei's release is state business and not his concern, but when Il'ia continues to press him, Grand Prince Vladimir loses his composure, exclaiming, "Не суйся не в свое дело! Я князь! Чего хочу, то и ворочу!" [“Don't intrude in business that is not yours! I'm the prince! I can do whatever I want!'’][06:20]. Then, sputtering, he realizes what he has said and tries to redeem himself, replacing ворочу (undo) with “Действую! В интересах державы!" [“I am acting! In the interests of the state!'] [06:24]. The prince seems to have some idea of the power 
and privileges proper for someone of his station, and he expects other people to uphold these norms; however, he does not have a corresponding awareness of the obligations and responsibilities of the ruler toward the people.

The grand prince continues to expect to enjoy the privileges of his station as the narrative moves toward Byzantium, Il'ia, however, has other ideas, and the dynamics of power between the two men quickly begin to shift. First, Il'ia refuses to take the entourage of soldiers and support staff Grand Prince Vladimir has gathered, robbing him of the pomp to which he is accustomed [21:12]. Il'ia further separates the grand prince from his own expectations by insisting that they send their horses back once they reach the edge of the forest [21:50]. Finally, when they stop for the night, Il'ia informs Grand Prince Vladimir that they will take turns keeping watch.

Илья: До полуночи ты стоишь в дозоре! [Il'ia: Until midnight, you will stand watch!]

BK: Я?! [GP: I?!?]

Илья: Ну да, ты! А что такого? Потом я тебя сменю. Здесь все равны, понял? Де-мо-кра-ти-я! На-ка, держи! [Il'ia: Yes you! And so what? Then I will spell you. Everyone is equal here, got it? De-mo-cra-cy! Here, take this!]

BК: Демократия ваша до смуты доведет! [GP: Your democracy will lead to turmoil!]

Илья: Княже! Чтоб глаз не смыкал! [25:02-25:26] [Il'ia:

Prince! Not a wink!] (translation mine)

This series of conversations exhibits several reversals in the expected dynamic of power between grand prince and epic hero. It is Il'ia who makes the decisions about who will go on this journey, when they will stop for the night, and who will take the first watch. The visual imagery further supports the new dynamics of power. 
Discursive Space

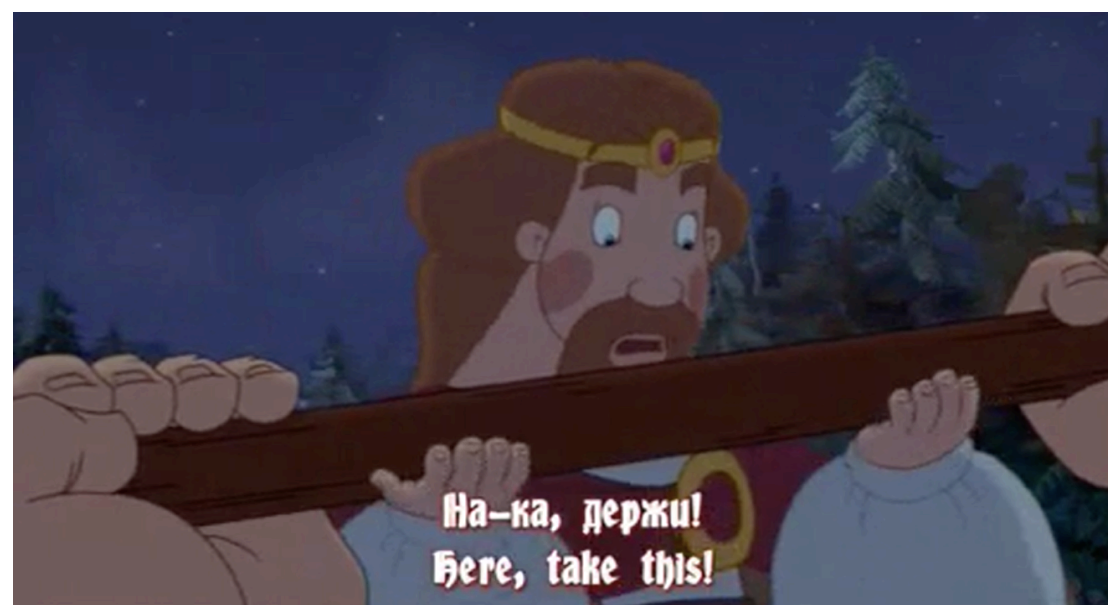

Image 2. Il'ia sets the watch. [25:18, Toropchin 2007]

Holding a spear as though he were the monarch bestowing a sword, Il'ia gives the weapon to Grand Prince Vladimir, tells him the first watch is his, and says, "democracy" slowly and deliberately, "demo-kra-ti-a," thereby overtly staking his claim to a new dynamic of power. In this scene, the creative team at Melnitsa visually highlights the differences between the two men. The grand prince's face expresses shock at the conversation they are having, and the perspective in the frame above showcases the daintiness of Grand Prince Vladimir's hands in his white sleeves. In contrast to the hero, the grand prince is practically childlike. It is also Il'ia who declares the terms of their relationship to include equal standing and democracy, although, rather than indicating equal partnership in decision making, the word "democracy" here seems to indicate the epic hero's usurpation of power.

Where Melnitsa's Grand Prince Vladimir cares more for money and power than for the welfare of his people, they present Il'ia Muromets as an epic hero, a protector who is intimately connected with the land and the people. This Il'ia draws his superlative epic hero strength from the earth of his homeland, and his connection with the land is revealed in his attentiveness to his surroundings, his affinity with animals, and his beliefs in superstitions and omens.

One of the more unusual features of Il'ia's nineteenth-century bylina corpus is a prose adventure, which relates how a young Il'ia 
was struck lame by disease in childhood and spent his days sleeping on top of the oven (a normal place for an invalid in a Russian peasant home) until at age thirty-three he was healed by traveling pilgrims, who predicted that he would become an important national hero. (16) Melnitsa's Ilya and the Robber, elides this sojourn on the oven, instead attributing the hero's superlative strength to physical contact with his homeland, although the film also problematizes this assertion. When Il'ia plans to pursue Solovei to Tsargrad [Byzantium], his mother becomes concerned about his loss of physical contact with the Rus' homeland. Il'ia shows no such concern and does not pause to accept the bag of earth she had prepared. Although she sends it after him, with the chronicler Алёнушка [Alënushka] [15:45], a series of misunderstandings and comic moments prevent his receiving it. The hero performs epic feats several times before suffering a failure of his strength when Grand Prince Vladimir points out his separation from his homeland. In that moment of revelation, Il'ia is left sapped until he finds some earth clinging to a horseshoe tucked inside his tunic. On one hand, the presence of the horseshoe in his tunic means that Il'ia never actually lost contact with his homeland, and his superlative strength should have stayed with him. If this is the case, however, the grand prince's questioning of Il'ia's strength should not have affected him

Similarly, Melnitsa presents Il'ia as a devout adherent to superstitions (17) as guiding principles, but questions the validity of these superstitions with the words and actions of other characters. Early scenes of the film present a series of portents: a black cat nearly crosses Il'ia's path [05:29], a fly lands in the milk [13:13], a bird in flight defecates on someone [17:08]. Like his epic strength, Il'ia's beliefs separate him from most of the other characters in the film. Il'ia's mother and Grand Prince Vladimir both mock his superstitions, and the prince orchestrates further bird blessings in an attempt to manipulate the hero. The only other character who shows respect for superstitions is a babushka in Byzantium [48:10] who scolds Solovei for whistling, noting, "Не свисти! Денег не будет. Примета такая." [“Don't whistle! You'll lose all your money. There's a superstition."] [51:40], and Solovei does indeed lose all the riches he had managed to acquire over the course of the film. 


\section{Putting Words in Their Mouths: Russian Byliny as Discursive Space}

More subtly, and more sincerely, presented than his adherence to superstitions, Il'ia's sympathetic connection to animals is critical to his success. When they quarreled early in the film, the epic hero threw his sword onto the table in front of the Grand Prince, thereby severing the tie between hero and state, without thinking twice, but paused when Vladimir demanded his horse as well. Only Solovei's theft of this horse brought Il'ia back to cooperation with Kiev's government [14:40]. While a strong friendship with his horse is not unusual for an epic hero, Il'ia's affinity for animals is more broad. As Il'ia and Grand Prince Vladimir moved through a forest, the hero is aware of his surroundings and listened to the background noise of the animals for information about what else was going on nearby [22:50]. In contrast, the grand prince was oblivious. Later, while in Byzantium, Grand Prince Vladimir and Il'ia both meet the same elephant but have very different interactions with him. While riding, the grand prince stabbed the elephant with a fork, making him bolt from the handler [52:28]. The elephant knew that he had broken the rules that constrain his life and was frightened when he finally came to a stop [53:50]. While Grand Prince Vladimir continued to act imperiously, Il'ia spoke softly and quietly, treating the elephant as a being worthy of respect [54:30]. Whereas he had been obedient to the handler because he feared the whip, the elephant was helpful to Il'ia because he appreciated the epic hero's regard.

This is not unexpected for an epic hero. Indeed, as Costlow and Nelson note in their introduction to Other Animals: Beyond Human in Russian Culture and History, "a central part of Russians' narratives about national identity has involved professions of a distinctive relationship to the natural world," a distinctive relationship that sets Russians apart from neighboring ethnic groups [2010: 3]. Il'ia's connections with his horse and the animals he hears in the forest, which are part of his native land, are an extension of his connection with the land. His interaction with the elephant, an exotic creature whom he meets in a land where they are both foreigners, portrays the habit for respectful interaction with and regard for elements of the natural world in a positive light.

Grand Prince Vladimir and Il'ia Muromets are not alone on their journey from Kiev to Tsargrad in Il'ia and the Robber. With 
self-referential humor, Melnitsa introduces the character of Alënushka, a chronicler, into this bylina film. Throughout Ilya and the Robber, Alënushka copies down the events of both the herovillain conflict and the hero-grand prince conflict on her birch bark tablet, implying that the story being told is contemporary with the Rus' chronicles. Her goal is a journalistic one: to get Il'ia Muromets's story for the Primary Chronicle. It is clear, however, from the other characters' reactions to Alënushka that they have no idea how to understand her, and she has to explain her chronicle project and show her notebook to Grand Prince Vladimir, Il'ia's mother, and Il'ia himself as she meets each of them. As a chronicler, Alënushka regards herself as a member of the press, an anachronism in a plot otherwise peopled by epic heroes and nobility, and she uses this status to claim a place in the grand prince's court.

Grand Prince Vladimir, however, is uninterested in a free press. He only allowed Alënushka into the audience chamber after his boyar reminded him, "Не пустишь, князь, а они опять гадость каку нацарапуют" ["If you don't allow them (to come in), prince, they will again print some kind of bold lies."] [07:27]. The grand prince nostalgically remembered a time when he would put writers such as these "В кандалы, темницы!" ["In chains, in the dungeon!’”, “А теперь, вишь, народ правду желает знать!” [“And now, look, the people want to know the truth!'] [09:02]. It was not, however, only his own people's thoughts he was concerned about, but also, "Что скажут на западе?" ["What will they say in the West?"] [09:03]. With regard to these considerations, the grand prince tolerated Alënushka's presence in the audience chamber briefly, but once messengers brought him news of Solovei's theft of the treasury and Il'ia's horse, he realized that he was no longer in control of the story Alënushka was recording. Grand Prince Vladimir then had her hauled out of his audience chamber for asking too many questions, and her shouts of "Свобода слова! Свобода прессы!" [“Freedom of the press! Freedom of speech!'”] [12:11] fell on deaf ears.

Once the grand prince, the hero, and the girl leave Kiev, the differences in the ways they approach the world are cast in striking relief as they navigate the foreign space. Both Alënushka and Grand 


\section{Putting Words in Their Mouths: Russian Byliny as Discursive Space}

Prince Vladimir have difficulty navigating the dangers in the forest and in the city of Tsargrad. (18) When she lags behind Il'ia and Grand Prince Vladimir in the forest, she is taken captive by Solovei's band of thugs, from whom Il'ia frees her. In Byzantium, Alënushka's naïve bravado does not protect her from being hoodwinked by a hustler who offers help [50:20], but then sells her to the Emperor as a slave [56:10]. The imperious demeanor with which Grand Prince Vladimir interacts with everyone he meets, including the elephant [54:25] and the emperor's palace guards [59:35], results in his being tossed into prison [01:02:30].

In contrast to Alënushka and Grand Prince Vladimir, Il'ia is able to navigate all three spaces; the familiar space of Kiev, the wild space of the forest, and the foreign space of Byzantium; equally well. Il'ia's kindness gains him a powerful new companion in the elephant [01:02:18], and he is able to rescue the grand prince, Alënushka, and his horse from captivity at the hands of the Byzantine emperor.

In the twenty-first century, cinema is simultaneously a carrier of globalization and a battleground for resistance. Hollywood exports American culture in its films, and other nations respond by exporting their own nationalist cultural products. [Hutchings 2008: 4] In this battleground, adaptations create critical, dynamic space for inter-cultural dialogue as cultural products are replicated in foreignto-them environments. New things first retain their sense of foreignness, then adapt even as they influence, and may later be exported back [Hutchings 2008: 6]. Melnitsa's "Disneyfication" of the nineteenth-century byliny offers a prime example of this. As they simplify the casts of characters and add romantic story arcs, they make the byliny resemble Disney's animated features while also making them more able to compete with those imported tales. In most eighteenth- and nineteenth-century versions of the byliny, the bogatyri, Prince Vladimir, and even the villain Solovei each have wives and children whose participation in the plot varies from backdrop to minor character. The situation of these men as settled adult members of society means that the issues of achieving manhood and finding a romantic partner are null. In Melnitsa's films, however, this is not the case. Solovei has a band of thugs 
rather than a family, and Il'ia finds romance as part of his journey within the film, as does Alësha in his film, and the grand prince's love interest is the topic of the group adventure in How Not to Rescue a Princess.

In his review of the literature related to "The Epos and the Fairy Tale in Russian Literary Criticism," Alex Alexander affirms the veracity of the model articulated by Константин Сергеевич Аксаков [Konstantin Sergeevich Aksakov] for differentiating epic from fairy tale. In the fairy tale, the magical element "is constantly present and almost all the heroes find support and help from the magical. In songs, on the other hand, although one cannot negate the presence of the supernatural element within, it is always on the side of the adversary." [Alexander 1973: 17] Although Il'ia's superstitions and Dobrynia's three-headed meditating dragon approach the magical, Melnitsa's corpus of bogatyr films largely remains on the bylina side of Aksakov's model, preserving the seminal differentiation that while geography on byliny may be less than precise, in tales, "the narrator abandons the boundaries of time and space." [380] However, the presentation of Il'ia Muromets as a younger man and the addition of romance and maturation plotlines in these films align them more closely with the genre of fairy tales than with the genre of epic. This alignment with fairy tales puts Melnitsa more directly in competition with the commercial hegemon that is the Disney Animation Studio. Melnitsa's corpus of animated bylina and fairy tale films offers a homegrown, nationalist alternative to the Disney canon.

In part the success of Melnitsa's films is nostalgic. Parents and grandparents fondly remember enjoying these stories as children and are happy to be able to share newer versions of them with today's children, and Il'ia and the Robber and the others can certainly be enjoyed on this level. If, however, we watch with a critical eye, we can see that the writers and artists at Melnitsa have used these medieval settings and characters as a backdrop for telling stories about current social issues like the relationship between the state and the people and the role of women in society.

In this 2007 adaptation of the story of Il'ia Muromets, Melnitsa ties the epic hero firmly to the Rus' motherland and then associates 


\section{Putting Words in Their Mouths: Russian Byliny as 101 Discursive Space}

democratic ideals with him, forming a chain of associations that connects democracy to Russianness. The characters the audience is invited to like, Il'ia and Alënushka, become the bridges that connect modern ideas to the golden age which contemporary Russian culture claims as its historical predecessor. By depicting Il'ia's positive interactions and his successful accomplishment of the goal to rescue his horse in contrast with the frustrated struggle that Grand Prince Vladimir experiences and the naïve vulnerability of Alënushka, the film ultimately posits that Il'ia's model of interaction with the world is the most successful. At the same time, however, the concept of democracy itself is problematized. Il'ia does not invite the Grand Prince and Alënushka to be part of his decision making process. Rather, he takes control and insists on his being in charge, creating his own benevolent dictatorship and calling it democracy. Later films in Melnitsa's filmography put the three epic heroes (Il'ia Muromets, Alësha Popovich, and Dobrynia Nikitich) on adventures together, again emphasizing democracy as the three men remind each other of their equality and make decisions together. They remain, however, self-appointed leaders of the people, or superhuman hero-leaders, not leaders by virtue of democratic choice among all the members of the populace. This presentation creates the implication that the ideals of democracy, freedom of speech, and freedom of the press can be as inherently Russian as love of the motherland and reverence for folk wisdom, but it also includes the need for protection of these ideas with the strength of an epic hero. In Il'ia and the Robber, Melnitsa masterfully blends entertaining comedy with deeper questions about cultural values. As they continue to produce animated bogatyr and fairy tale films, scholars would do well to pay attention to the changes they make in the process of adaptation as a bellwether of socio-cultural trends and identity politics in Russia today.

\section{NOTES}

1 While a faithful transliteration of the Russian word мельница [windmill] in the system I am using would be mel'nitsa, I have chosen to follow the animation studio's own transliteration of 
their name.

2 Recording, adaptation, and scholarly interaction have influenced both the presentation and the interpretation of this genre. Nineteenth-century scholars regarded the byliny as a natural class distinct from other types of oral texts, but singers and their audiences may not have agreed. Indeed, the label 'bylina' was introduced by the scholar Иван Петрович Сахаров [Ivan Petrovich Sakharov] in the 1830s [Bailey and Ivanova 1998: xx]. Performers, however, called these starinki or stariny [old songs] and grouped them together with other forms of song, like mythological epics, religious verses, and historical songs [Bailey and Ivanova 1998: xxvi]. Once recorded, the byliny existed in both oral and literary forms, which were mutually influential as a story was recorded and published, then read and retold, then possibly recorded and published again in a slightly altered form until the mid-twentieth century. For the broader context of oral heroic epics, see Lord, Albert Bates The Singer of Tales.

3 Generally, I have followed the paradigm for transliterating Russian Cyrillic into the Latin alphabet mandated by this journal. In the case of quoted text from other scholars, I have silently amended their transliterations to harmonize the presentation of names throughout this chapter. Where personal names and titles, such as tsar, already have standard spellings in English, I have followed them.

4 Most notably, Кирша Данилов (Fl. 1750) [Kirsha Danilov], Пётр Васильевич Киреевский (1808-1856) [Pёtr Vasil'evich Kireevskii], Павел Николаевич Рыбников (1831-1885) [Pavel Nikolaevich Rybnikov], and Александр Фёдорович Гильфердинг (1831-1872) [Aleksandr Fëdorovich Gil'ferding].

5 Novgorod the Great, a member city of the Hanseatic League, dominated river trade between the Baltic Sea and the Caspian Sea, while also sending out colonial projects reaching as far as Western Siberia. This northern power operated with an oligarchy and a citizen assembly. For a general overview of Russian history, see Nicholas Valentine Riasanovsky and Mark D. Steinberg, A History of Russia, $6^{\text {th }}$ edition, and for medieval Russia, Janet Martin, Medieval Russia 980-1584, $2^{\text {nd }}$ ed. and Simon Franklin and Jonathan 


\section{Putting Words in Their Mouths: Russian Byliny as 103 Discursive Space}

Shepherd, The Emergence of Rus 750-1200. About Novgorod's history, Henrik Birnbaum, Lord Novgorod the Great: The Historical Background, vol. 2; Charles Halperin, "Novgorod and the 'Novgorodian Land'," Cahiers du Monde russe. About the veche and the means of its power see Jonas Granberg, "Veche in the Chronicles of Medieval Rus: A Study of Functions and Terminology." On the Hanseatic League, see Donald J. Harreld, A Companion to the Hanseatic League and Janet Martin, "Novgorod: The Squirrel Fur Trade," Treasures of the Land of Darkness: The Fur Trade and Its Significance for Medieval Russia, 61-85.

6 On Kiev's connection to Byzantium, see Simon Franklin, Byzantium-Rus-Russia: Studies in the Translation of Christian Culture. On Kiev as a part of Europe, see Christian Raffensperger, Reimagining Europe: Kievan Rus' in the Medieval World. On the structure of the principality, see Nancy Shields Kollmann, "Collateral Succession in Kievan Rus'," Harvard Ukrainian Studies.

7 The princes of Rus' city states in the Kievan period built households of druzhina, [military retinue] and boiare [members of the court] to control resources and trade. According to Bailey and Ivanova, among the city states there was "complex system of collateral succession by seniority within generations, the senior member of the princely family became the grand prince in the city of Kiev, while other members received ruling positions in other cities" [1998: xviii].

8 For a more nuanced discussion of this transformation of adversaries, see Bailey and Ivanova, Anthology, xvii-xx.

9 For more on the establishment and consolidation of Soviet cinema, see the other selections in Russia on Reels and Stephen Hutchings, "Introduction," in Russia and Its Other(s) on Film: Screening Intercultural Dialogue, 1-22. For more on national identity, see "Nicholas II and the Collapse of the Romanov State" in Zhand Shakibi, Revolutions and the Collapse of the Monarchy: Human Agency and the Making of Revolution in France, Russia and Iran. On the role of folklore in the early Soviet Union, see Felix J. Oinas, "Folklore Activities and Scholarship in Russia," Essays on Russian Folklore and Mythology. For an extended discussion of the 
notion of folklore in a classless society, as the Soviet Union claimed to be, see Felix Oinas, "The Problem of the Notion of Soviet Folklore," Essays on Russian Folklore and Mythology, 161-79.On the role of fairy tale films, see Marina Balina and Birgit Beumers, "To Catch Up and Overtake Disney?: Soviet and Post-Soviet Fairy Tale Films," Fairy Tale Films Beyond Disney.

10 Sergei Mikhailovich Eisenstein's 1925 film Броненосеय, Потемкин [Battleship Potemkin] inspires with references to key historical events and figures, while those like Yakov Aleksandrovich Protazanov's 1925 Закройщик из Торжка [The Tailor from Torzhok] celebrate the experiences of the Soviet citizen. Through the 1930's both the pattern of looking to historical events and figures for inspiration and the celebration of the experiences of everyday citizens persist. Eisenstein's 1938 Александр Невский [Alexander Nevsky] reminds Soviet citizens of Russia's historic success against western European aggression at a time of increased tension with Nazi Germany. Meanwhile, Stalinist musical comedies like the 1938 Волга Волга [Volga-Volga] continue to bring images of an idealized Soviet everday life to the screen.

11 Seth Graham, "Chernukha and Russian Film," Studies in Slavic Cultures offers an overview of development of the chernukha genre, and its long dominance artistic-cinematic conversation from the mid-1980's to the late 1990's. Even as some directors begin to create more hopeful films, the visual program of the chernukha genre and the habits of depiction continue to dominate these films.

12 See also Graham's discussion of the chernukha as an artistic inversion of melodrama, both of which express themeselves through excess [Graham 2000: 11].

13 Melnitsa's corpus of bogatyr films is open to criticism regarding the representations of Others. In Alosha, the adversaries are overtly identified as being both Тугары [Tugars] [03:35] and басурмане [basurmane, foreigners or people of another faith ][05:00]. The Tugars are a fictional people invented as a stand-in for the historical Tatars. They first make their appearance in the liveaction film, Илья Муромеи [Il'ia Muromets, The Sword and the Dragon] from 1956. In Dobrynia and the Dragon, the adversaries conform to stereotypes of Otherness (facial features, skin tone, 


\section{Putting Words in Their Mouths: Russian Byliny as 105 Discursive Space}

yurts, demands for tribute) and are overtly identified as part of the Crimean Khanate [03:57]. Further, they are depicted as lacking both cunning and prowess. In addition, Rus' space is presented as more lush than non-Russian space as we watch Dobrynia ride out along the border, which is green on the Rus' side and brown on the other side [02:06].

14 For more on collusion with a knowing audience, see Linda Hutcheon, "Knowing and Unknowing Audiences," A Theory of Adaptation, 120-27. See also Brian McFarlane, Novel to Film: An Introduction to the Theory of Adaptation. For an alternate view, see Olga Lyanda-Geller's "Masha and Bear(s): a Russian Palimpsest."

15 To avoid ambiguity, the English title of this film will be used. However, it should be noted that the dubbed (and recut) English language release of this film titled The Sword and the Dragon takes broad liberties with translation.

16 The bogatyr Il'ia Muromets, however, is not the only figure in Russian popular culture to have a story like this. He is sometimes associated with the Russian Orthodox Saint Илия Печерский [Il'ia Pechorskii], who died in 1188 and was beatified in 1643, and whose relics reside at the Киево-Печерская лавра [Kievo-Pecherskaia Lavra, the Kiev Monestary of the Caves]. For evidence of popular association of epic hero and saint, see "Ilya Muromets" at Wikipedia.org and John Sanidopoulos's post "Saint Elias (Ilya) Muromets of the Kiev Near Caves" at Mystagogy. Bailey and Ivanova do not support this identification [Anthology, 25]. Емеля Дурачок [Emelia Durachok, the Fool], hero of the eponymous Russian fairytale, also sleeps on top of the stove, although he is motivated by sloth rather than illness, and his story is one of a cluster of "lazy boy" tales (ATU 675). For more on this point, see Bailey and Ivanova, Anthology, 26 and Oinas, "Russian Byliny," Essays on Russian Folklore, 9-31. On sloth in lazy boy tales, see Bottigheimer's article "Luckless, Witless, and Filthy-Footed: A Sociocultural Study and Publishing History Analysis of 'The Lazy Boy." More broadly, there is a similar phenomenon represented in the Norse lygisögur, namely a 'kolbitr, literally 'coal-biter,' or male-Cinderella figure, who appears to be lazy or slow-witted, but eventually proves himself" [Matthew Driscoll 2005: 200]. The 
Grettir of Grettir's Saga is a slothful and contrary example of the lazy boy. His inactivity is largely motivated by a desire to thwart his father's directives, and when he can no longer manage to avoid work, Grettir works transgressively: killing the geese and goslings in his charge and scratching his father's back with a wool comb [Chapter 14]. The kolbitr tend to be represented as having chosen their sloth and laziness. For more on the prevalence of kolbitrs in Icelandic sagas see Inger M. Boberg's Motif Index of Early Icelandic Literature.

17 The Russian word that the characters within the film use to label these beliefs is примета, which generally translates as omens or portents. However, belief in the bad luck of black cats and the good luck of bird feces would generally be referred to as superstitions in English, which in Russian would be суеверия. Because the attitudes of the characters in the film toward the приметь resembles the attitudes I would describe in American English as superstitious or not superstitious, I have chosen to use that word to discuss the beliefs here.

18 Costlow, and Nelson, eds., "Introduction": "Russian culture has been and remains an imperial project where 'Russianness' is infused with and relies on complex patterns of domination, interaction, and codependence with a myriad of non-Russians" [3]. In this film, Kiev exists in opposition to both the east and the west. Grand Prince Vladimir would like to dominate the east with the capture of Solovei (and demanding of tribute in the Dobrynia film) while also moving closer to equality with Byzantium. The emperor, however, regards the grand prince as unworthy of attention.

\section{BIBLIOGRAPHY}

Aleksandrov, Grigori, dir. 1938. Александров, Григорий. Волга Голга [Volga Volga]. Perf. Igor Ilyinski, Vladimir Volodin, Pavel Olenov. Moscow: Mosfilm.

Alexander, Alex E. 1973. Bylina and Fairy Tale: The Origins of Russian Heroic Poetry The Hague: Mouton.

Bailey, James and Tatyana Ivanova, eds. and trans. 1998. An Anthology of Russian Folk Epics. New York: M.E. Sharpe. 


\section{Putting Words in Their Mouths: Russian Byliny as 107 Discursive Space}

Balina, Marina and Birgit Beumers. 2016. "To Catch Up and Overtake Disney?': Soviet and Post-Soviet Fairy Tale Films," Fairy Tale Films Beyond Disney: International Perspectives. Jack Zipes, Pauline Greenhill, and Kendra Magnus-Johnston, eds. New York: Routledge.

Beumers, Birgit, ed. 1999. Russia on Reels: The Russian Idea in Post-Soviet Cinema. New York: I. B. Tauris.

Beumers, Birgit. 1999. "Introduction," in Russia on Reels: The Russian Idea in Post-Soviet Cinema. Birgit Beumers, ed. New York: I. B. Tauris, 1-11.

Birnbaum, Henrik. 1981. Lord Novgorod the Great: The Historical Background, vol. 2. Columbus, $\mathrm{OH}$ : Slavica Publishers.

Boberg, Inger M. 1966. Motif Index of Early Icelandic Literature.

Bibliotheca Arnamagnæana 27. Copenhagen: Munksgaard.

Bottigheimer, Ruth. 1993. "Luckless, Witless, and Filthy-Footed: A Sociocultural Study and Publishing History Analysis of 'The Lazy Boy,'” The Journal of American Folklore 106 (421): 259284.

Bronzit, Konstantin, dir. 2004. Бронзит, Константин. Алеша Поповичь и Тугарин Змей [Alësha Popovich and Tugarin Snake]. Perf. Oleg Kulikovich, Lia Medvedeva, Dimitri Vysotsky. St. Petersburg: Melnitsa Animation Studio.

Costlow, Jane and Amy Nelson, (eds.). 2010. "Introduction," in Other Animals: Beyond the Human in Russian Culture and History. Pittsburgh: University of Pittsburgh Press, 1-15.

Danilov, Kirsha. 1804. Данилов, Кирша. Древнія россійскія стихотворенія, собранныя Киршею Даниловымь [Old Russian Poetry Collected by Kirsha Danilov]. Москва: Типографія Семена Селивановскаго.

Driscoll, Matthew. 2005. "Late Prose Fiction (lygisögur)," in $A$ Companion to Old Norse-Icelandic Literature and Culture.

Rory Mcturk, ed. London: Blackwell Publishing, 190-204.

Eisenstein, Sergei, dir. 1925. Эйзенштейн, Сергей. Броненосеи Потемкин [Battleship Potemkin]. Perf. Aleksandr Antonov, Vladimir Barsky, and Grigori Aleksandrov. Москва: Госкино. Eisenstein, Sergei, dir. 1938. Эйзенштейн, Сергей. Александр Невский [Alexander Nevsky]. Perf. Nikolai Cherkasov, 
Nikolai Okhlopkov, and Andrei Abrikosov. Москва: Мосфильм.

Feoktisov, Konstantin, dir. 2012. Феоктисов, Константин. Три Богатыря на Дальних Берегах [Three Heroes on Distant Shores]. Perf. Fedor Bondarchuk, Elizaveta Boyarskaya, Dmitri Bykhovski. St. Petersburg: Melnitsa Animation Studio.

Franklin, Simon and Jonathan Shepherd. 1996. The Emergence of Rus 750-1200. London: Longman.

Franklin, Simon. 2002. Byzantium-Rus-Russia: Studies in the

Translation of Christian Culture. Aldershot: Variorum.

Gilferding, Aleksandr Fëdorovich. 1873. Гильфердинг, Александр

Фёдорович. Онежские былины записанные Александром

Федоровичем Гильфердингом летом 1871 [Onega Bylini

Written Down by Aleksandr Fëdorovich Gilferding in the

Summer Of 1871]. Санктпетербург: Тип. Императорской

Академии Наук.

Gillespie, David. 1999. "New Versions of Old Classics: Recent

Cinematic Interpretations of Russian Literature," in Russia on

Reels: The Russian Idea in Post-Soviet Cinema. Birgit

Beumers, ed. New York: I. B. Tauris, 114-24.

Glezin, Sergei, dir. 2010. Глезин, Сергей. Три Богатыря $u$

Шамаханская Принщесса [Three Bogatyr and Princess

Shamakhanskaya or "How Not to Rescue a Princess"]. Perf.

Valeriy Solovyov, Anna Geller, Oleg Kulikhovich. St.

Petersburg: Melnitsa Animation Studio.

Graham, Seth. 2000. "Chernukha and Russian Film," Studies in Slavic Cultures 1: 9-27.

Granberg, Jonas. 2004. "Veche in the Chronicles of Medieval Rus:

A Study of Functions and Terminology." Diss. University of Gothenburg.

Halperin, Charles. 1999. "Novgorod and the 'Novgorodian Land',"

Cahiers du Monde russe 40: 345-63.

Harreld, Donald J. 2015. A Companion to the Hanseatic League. Leiden: Brill.

Hutcheon, Linda. 2013. A Theory of Adaptation. 2nd ed. New York: Routledge.

Hutchings, Stephen. 2008. "Introduction," in Russia and Its Other(s) 


\section{Putting Words in Their Mouths: Russian Byliny as 109 Discursive Space}

on Film: Screening Intercultural Dialogue. Stephen Hutchings, ed. New York: Palgrave Macmillan, 1-22.

"Ilya Muromets." 2016. Wikipedia.org Cited by https://en.wikipedia.org/wiki/Ilya_Muromets (consulted May 2016).

Kireevskii, Pëtr Vasil'evich. 1860-1874. Киреевский, Пётр Васильевич. Птьсни, собранныл П.В. Киргевским Bыл. 1-10 [Songs Collected by P. V. Kireevskii Issues 1-10]. Москва: Типографія А. Семена, и т.д.

Kollmann, Nancy Shields. 1990. "Collateral Succession in Kievan Rus'," Harvard Ukrainian Studies 14: 377-87.

Likhachev, D. S., O. V. Tvorogov, A. G. Bobrov, S. L. Nikolaev, Andre ̌ Chernov, and Miud Mar'evich Mechev. 2012. Лихачев,

Д. С., О. В. Творогов, А. Г. Боборов, С. Л. Николаев, Андрей Чернов, и Миюд Марьевичь Мечев. Повесть временных лет [Tale of Bygone Years or "Primary Chronicle"]. Saint Petersburg: Vita Nova.

Lord, Albert Bates. 2000. The Singer of Tales. Stephen Arthur Mitchell and Gregory Nagy, eds. Cambridge: Harvard University Press.

Lyanda-Geller, Olga. 2015. "Masha and Bear(s): A Russian Palimpsest," Folklorica 19: 75-99.

MacFaden, David. 2005. Yellow Crocodiles and Blue Oranges: Russian Animated Film since World War II. Montreal: McGill University Press.

Maksimov, Ilya, dir. 2006. Максимов, Илья. Добрыня Никитич и Змей Горыныц [Dobrinya and the Dragon]. Perf. Mikhail Chernyak, Natalya Danilova, Ekaterina Gorokhovskaya. St. Petersburg: Melnitsa Animation Studio.

Martin, Janet. 2004. Treasures of the Land of Darkness: The Fur Trade and Its Significance for Medieval Russia. Cambridge: Cambridge University Press, 61-85.

Martin, Janet. 2007. Medieval Russia 980-1584, 2nd ed. Cambridge: Cambridge University Press.

McFarlane, Brian. 1996. Novel to Film: An Introduction to the Theory of Adaptation. Oxford: Oxford University Press.

Niles, John D. 1999. Homo Narrans: The Poetics and Anthropology 
of Oral Literature. Philadelphia: The University of Pennsylvania Press.

Oinas, Felix J. 1985. Essays on Russian Folklore and Mythology. Columbus, OH: Slavica Publishers.

Protazanov, Yakov, dir. 1925. Протазанов, Яков. Закройщик из Торжка [The Tailor from Torzhok]. Perf. Igor Ilyinsky. Moscow: Mezhrabpom-Russ.

Ptushko, Aleksandr, dir.1956. Птушко, Александр. Илья муромеи [Ilya Muromets; or, The Sword and the Dragon]. Perf. Boris Andreyev, Shukur Burkhanov, Andrei Abrikosov. Moscow: Mosfilm.

Raffensperger, Christian. 2012. Reimagining Europe: Kievan Rus' in the Medieval World. Cambridge, MA: Harvard University Press.

Riasanovsky, Nicholas Valentine and Mark D. Steinberg. 2010. $A$ History of Russia, 6th edition. Oxford: Oxford University Press. Rybnikov, Pavel Nikolaevich. 1861-1867. Рьбников, Павел Николаевич. Птьсни собранныя П. Н. Рыбниковым [Songs Collected by P. N. Rybnikov]. Москва: Типогрпфія А. Семена.

Sanders, Julie. Adaptation and Appropriation. London: Routledge, 2006.

Sanidopoulos, John. 2010. "Saint Elias (Ilya) Muromets of the Kiev

Near Caves." Mystagogy Resource Center: An Internation Orthodox Christian Ministry. Cited by http://www.johnsanidopoulos.com/2010/12/saint-elias-ilyamuromets-of-kiev-near.html (consulted October 2015).

Schmidt, Darina, dir. 2007. Шмидт, Дарина. Маленькая Василиса [Little Vasilisa]. Perf. Kira Zamorina, Konstantin Bronzit, Oleg Kulikovich. St. Petersburg: Melnitsa Animation Studio.

Shakibi, Zhand. 2007. Revolutions and the Collapse of the Monarchy: Human Agency and the Making of Revolution in France, Russia and Iran. London: I. B. Tauris.

Taylor, Richard. 1999. "Preface," in Russia on Reels: The Russian Idea in Post-Soviet Cinema. Birgit Beumers, ed. New York: I. B. Tauris, vii.

Toropchin, Vladimir, dir. 2007. Торопчин, Владимир. Илья 


\section{Discursive Space}

Муромеи и Соловей Разбойник [Il'ia and Nightingale the Robber]. Perf. Valeri Solovyev, Sergey Makovetskiy, and Oleg Tabakov. St. Petersburg: Melnitsa Animation Studio.

Toropchin, Vladimir, dir. 2011. Торопчин, Владимир. Иван Царевич и Серый Волк [Ivan Tsarevich and the Grey Wolf]. Perf. Liya Alhedzhakova, Kristina Asmus, Mikhail Boyarskiy. St. Petersburg: Melnitsa Animation Studio. 